УДК 663.263

DOI 10.30679/2219-5335-2019-3-57-159-168

ОБОСНОВАНИЕ

ПАРАМЕТРОВ И РЕЖИМОВ

БАТОНАЖА

В ТЕХНОЛОГИИ КРАСНЫХ

СТОЛОВЫХ ВИН

Агеева Наталья Михайловна

д-р техн. наук, профессор

главный научный сотрудник

научного центра «Виноделие»

e-mail: ageyeva@inbox.ru

Бирюкова Светлана Александровна, аспирант

e-mail:s.biryukova@meil.ru

Федеральное государственное

бюджетное научное учреждение

«Северо-Кавказский федеральный

научный иентр садоводства,

виноградарства, виноделия»,

Краснодар, Россия

Лисовец Ульяна Александровна, аспирант,

e-mail: ulianapost@yandex.ru

Кубанский государственный

технологический университет,

Краснодар, Россия

Батонаж - технологический приём, представляющий собой продолжительный контакт виноматериала с дрожжевым осадком, с периодическим взмучиванием среды. Его применение в технологии белых столовых вин приводит к улучшению их вкуса и аромата за счёт обогащения вина компонентами дрожжевой клетки. Специфика красных столовых вин заключается в наличии высоких концентраций фенольных соединений, влияющих на процесс метаболизма между клеткой и виноматериалом. Режимы проведения батонажа при производстве красных вин
UDC 663.263

DOI 10.30679/2219-5335-2019-3-57-159-168

\section{SUBSTANTIATION \\ OF THE PARAMETERS \\ AND BATONAGE REGIMES \\ IN THE TECHNOLOGY \\ OF THE RED TABLE WINES}

Ageyeva Natalia Mikhailovna
Dr. Sci. Tech., Professor
Chief Research Associate
of SC «Wine-making»
e-mail: ageyeva@inbox.ru

Biryukova Svetlana Aleksandrovna

Post graduate student

e-mail:s.biryukova@meil.ru

Federal State Scientific

Budget Institution "North-

Caucasian Federal Scientific

Center of Horticulture,

Viticulture, Winemaking»,

Krasnodar, Russia

Lisovets Uliyana Aleksandrovna

Post graduate student

e-mail: ulianapost@yandex.ru

\section{Kuban State University}

of Technology,

Krasnodar, Russia

Batonage is a technological method, which is a prolonged contact of wine materials with yeast sediment, with occasional stirring. Batonage`s use in the technology of white table wines leads to an improvement in their taste and aroma due to the enrichment of wine with yeast cell components. The specificity of red table wines is the presence of high concentrations of phenolic substantiate that affect the metabolism process between the cell and the wine material. Modes of batonage in the production of red wines should take into account 
должны учитывать наличие различных форм полифенолов. В связи с этим цель работы заключалась в обосновании параметров и режимов батонажа в технологии красных вин. В результате проведённых исследований установлена секреция гидролитических ферментов и липидов из дрожжевой клетки в виноматериал. Активность протеиназ и глюканаз в дрожжевой биомассе по мере выдержки снижалась, достигая наименьших значений через 1,5 месяца. В процессе батонажа снижалась также концентрация как суммы фенольных соединений, так и антоцианов. При этом двукратное проведение Батонажа способствовало большему Снижению концентрации фенольных соединений. Полученные результаты свидетельствуют о замедленной динамике перехода липидов из дрожжевой клетки в среду в процессе батонажа. Из отдельных компонентов жирнокислотного ряда наиболее заметно в процентном отношении возрастала концентрация диглицеридов и триглицеридов, а также эфиров стеринов. Понижение температуры контакта виноматериала с дрожжевой биомассой приводило к замедлению процессов массообмена между клеткой и средой. На основании результатов исследований даны рекомендации производству по режимам проведения батонажа.

Ключевые слова: КРАСНЫЕ СТОЛОВЫЕ ВИНА, БАТОНАЖ, ДРОЖЖИ, ТЕМПЕРАТУРА, ПРОДОЛЖИТЕЛЬНОСТЬ КОНТАКТА, ФЕНОЛЬНЫЕ СОЕДИНЕНИЯ the presence of various forms of polyphenols. In this regard, the purpose of the work was to justify the parameters and modes of batonage in the technology of red wines. As a result of the research, the secretion of hydrolytic enzymes and lipids from the yeast cell to the wine material was established. The activity of proteinases and glucanases in yeast biomass decreased as they matured, reaching the lowest values after 1.5 month. During the batonage, the concentration of both the sum of phenolic compounds and anthocyanins also decreased. At the same time, double batonage contributed to a greater decrease in the concentration of phenolic compounds. The results obtained indicate a slow dynamics of the transition of lipids from yeast cell to the medium during the batonage process. Of the individual components of the fatty acid series, the concentration of diglycerides and triglycerides, as well as sterol esters, increased most noticeably in percent. Lowering the temperature of contact of the wine material with yeast biomass led to a slowdown in the processes of mass transfer between the cell and the medium. Based on the results of the research, the recommendations were given to the producters according to the batonage regime.

Key words: RED TABLE WINES, BATONAGE, YEAST, TEMPERATURE, CONTACT DURATION, PHENOL COMPOUNDS

Введение. Батонаж (от фран. bâtonnage) - технологический прием, применяемый в ходе выдержки вина на дрожжевом осадке. Его сущность заключается в том, что осадок винных дрожжей, находящийся на дне резервуара, периодически взмучивают специальным шестом - батоном $[1,2]$. Считается, что в результате проведения батонажа виноматериалы обога- 
Плодоводство и виноградарство Юга России № 57(03), 2019 г.

щаются ценными продуктами метаболизма дрожжевой клетки - сложными эфирами, липидами, аминокислотами [3-6]. Это придаёт вину насыщенный сливочный вкус, способствует усилению ассимиляции танинов древесины дуба в случае выдержки вина в бочках, протеканию побочных реакций, преимущественно восстановительного характера. Батонаж обычно рекомендуют для улучшения качества белых столовых вин.

Практически отсутствуют экспериментальные данные о целесообразности проведения батонажа в технологии красных столовых вин. Однако исследования, проведённые Е.Н. Датунашвили, Н.М. Павленко, В.И. Ниловым, С.П. Авакянцем ещё в семидесятые годы прошлого столетия, свидетельствуют о том, что в результате непродолжительного контакта красного столового вина с дрожжевой гущей улучшаются органолептические характеристики продукции, а виноматериал обогащается гидролитическими ферментами $[7,8]$.

Исследованию секреции белка и ферментов из дрожжевой клетки в белый столовый виноматериал посвящён ряд работ $[9,10,11]$. Однако учитывая специфику красных столовых вин в сравнении с белыми, можно считать, что параметры и режимы батонажа должны быть различными. Особенность красных столовых вин заключается в наличии высоких концентраций фенольных соединений, которые могут взаимодействовать с поверхностью дрожжевой клетки и оказывать существенное влияние на секрецию различных компонентов из дрожжевой клетки в среду. Кроме того известно, что поверхность дрожжевой клетки обладает электростатическими свойствами и может сорбировать многие компоненты виноматериалов за счёт физико-химического взаимодействия. В связи с этим исследование выдержки красных столовых виноматериалов на дрожжевом осадке является актуальной задачей.

Цель данной работы - обоснование параметров и режимов батонажа в технологии красных столовых вин. 
Плодоводство и виноградарство Юга России № 57(03), 2019 г.

Объекты и методы исследований. Красные столовые виноматериалы, произведённые из сорта винограда Каберне-Совиньон, по окончании брожения (активные сухие дрожжи расы Оеноферм Руж) выдерживали в контакте с дрожжевой биомассой в течение 3-х месяцев. Перемешивание суспензии проводили 2 раза в месяц по 30 минут. Активность ферментов вина и дрожжевой биомассы определяли по известным методикам $[12,13]$; массовую концентрацию фенольных соединений - колориметрическим методом с применением реактива Фолина-Чокальтеу [14].

Обсужнение результатов. Известно, что автолизующиеся дрожжевые клетки являются источником гидролитических ферментов, в том числе инвертазы и протеаз, пектиназ, ускоряющих ферментативные превращения в вине $[15,16]$. Выделение дрожжами ферментов в среду зависит от физиологической активности клеток. В стационарной фазе развития, когда жизнь клетки прекращается, интенсивно происходят автолитические процессы, а внутриклеточные ферменты сохраняются. В технологии красных вин выдержку виноматериала на дрожжах проводят в строго анаэробных условиях с целью профилактики окислительных реакций $[8,17]$. В связи с этим автолитические процессы усиливаются, протекают активно, так как при недостатке кислорода в клетке активизируются гидролитические ферменты.

Исследовали изменение активности ферментов - глюканазы, протеиназ и пектиназ - в процессе батонажа красного столового виноматериала Каберне-Совиньон.

Проведённые исследования показали, что в сравнении с белыми виноматериалами $[8,9,10]$ при батонаже красных виноматериалов несколько изменяется тенденция изменения активности ферментов (табл. 1).

Активность протеиназ в дрожжевой биомассе по мере выдержки снижается. Особенно заметно это уменьшение через 1,5 месяца батонажа. Дальнейшее увеличение продолжительности контакта дрожжей с виноматериалом приводит лишь к незначительному уменьшению активности протеиназ - 
Плодоводство и виноградарство Юга России № 57(03), 2019 г.

на 6,2 \%. Это говорит о том, что переход высокомолекулярных соединений из клетки в среду затруднён, что, возможно, связано с высокой концентрацией фенольных соединений, блокирующих мембрану клеток $[17,18]$.

Таблица 1 - Активность ферментов в дрожжевой биомассе и виноматериале в процессе батонажа

\begin{tabular}{|c|c|c|c|c|c|c|c|c|}
\hline \multirow{3}{*}{ 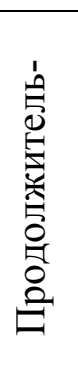 } & \multirow{3}{*}{ 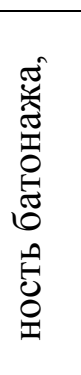 } & \multirow[b]{3}{*}{$\stackrel{ن}{\tilde{\Sigma}}$} & \multicolumn{6}{|c|}{ Активность ферментов, усл. ед } \\
\hline & & & \multicolumn{3}{|c|}{ в дрожжевой биомассе } & \multicolumn{3}{|c|}{ в красном виноматериале } \\
\hline & & & 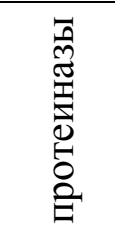 & 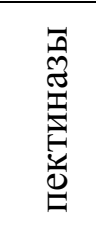 & 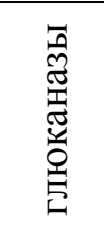 & 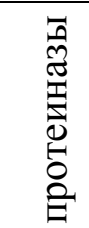 & 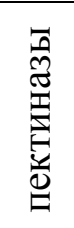 & 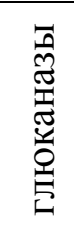 \\
\hline & 0,5 & & 202,6 & 26,4 & 22,7 & 15,6 & 5,8 & 1,8 \\
\hline & 1,0 & & 186,6 & 21,2 & 16,4 & 18,2 & 6,2 & 1,8 \\
\hline & 1,5 & & 154,7 & 17,6 & 14,2 & 15,4 & 4,4 & 1,4 \\
\hline & 2,0 & & 150,6 & 15,2 & 13,0 & 11,8 & 2,4 & нет \\
\hline & 2,5 & & 144,8 & 14,3 & 12,2 & 8,8 & 1,7 & нет \\
\hline & 3,0 & & 137,7 & 14,0 & 12,2 & 7,6 & 1,4 & нет \\
\hline
\end{tabular}

Активность протеиназ в красном виноматериале в течение 1 месяца контакта увеличилась, по мере дальнейшей выдержки отмечено снижение её значений. Таким образом, активность пектиназ в дрожжевой биомассе и виноматериале в процессе наблюдения постоянно снижалась, особенно в течение 1,5 месяцев.

Глюканазы показали наименьшую интенсивность секреции из дрожжевой клетки в виноматериал. Их активность фиксировалась только в течение 1,5 месяцев, после чего глюканазы в виноматериале не обнаруживались, что согласуется с данными, приведёнными в литературных источниках $[15,16]$. Анализируя полученные результаты, можно отметить, что в процессе контакта с дрожжевой биомассой в виноматериал из дрожжей переходит лишь от 5 до 10 \% протеиназ, от 10 до 22 \% пектиназ, от 0 до 7,5 \% глюканаз. Это свидетельствует о наличии биохимических барьеров на границе между клеткой и средой, препятствующих секреции ферментов при батонаже. 
Плодоводство и виноградарство Юга России № 57(03), 2019 г.

На основании приведённых экспериментальных данных можно считать, что активное протекание массообменных процессов при батонаже в технологии красных столовых вин завершается через 1,5 месяца.

Исследована динамика перехода липидов из дрожжевой клетки в среду в процессе продолжительного контакта винных дрожжей с виноматериалом. Известно, что диффузию липидов, как правило, связывают с изменением проницаемости мембраны клеток [19-21]. Полученные результаты свидетельствуют о замедленной динамике перехода липидов из дрожжевой клетки в среду в процессе батонажа (табл. 2).

\section{Таблица 2 - Изменение концентрации липидов в процессе батонажа, мг/дм ${ }^{3}$}

\begin{tabular}{|l|c|c|c|c|c|}
\hline \multirow{2}{*}{\multicolumn{1}{|c|}{ Липиды }} & \multirow{2}{*}{ До батонажа } & \multicolumn{4}{|c|}{ Продолжительность батонажа, месяцев } \\
\cline { 3 - 6 } & & 1,0 & 1,5 & 2,0 & 2,5 \\
\hline Фосфолипиды & 10,7 & 10,9 & 12,6 & 13,3 & 12,6 \\
\hline Пигменты & 13,7 & 14,0 & 14,8 & 14,7 & 12,2 \\
\hline Стерины & 10,4 & 10,6 & 11,1 & 11,5 & 10,5 \\
\hline Моноглицериды & 7,7 & 7,7 & 9,2 & 9,6 & 9,7 \\
\hline Диглицериды & нет & 0,18 & 0,31 & 0,38 & 0,32 \\
\hline Жирные кислоты & 8,4 & 8,8 & 11,2 & 13,2 & 10,4 \\
\hline Триглицериды & 5,5 & 6,0 & 7,2 & 8,3 & 7,2 \\
\hline Эфиры стеринов & следы & 0,18 & 0,31 & 0,42 & 0,37 \\
\hline Сумма липидов & 56,4 & 58,36 & 66,72 & 72,40 & 59,89 \\
\hline
\end{tabular}

Из отдельных компонентов жирнокислотного ряда наиболее заметно в процентном отношении возрастала концентрация диглицеридов и триглицеридов, а также эфиров стеринов. При этом на первом месяце выдержки виноматериала на дрожжевом осадке диглицериды и эфиры стеринов в виноматериалах отсутствовали. По мере выдержки увеличивалась концентрация жирных кислот. Количество моноглицеридов возросло в меньшей степени. Наибольшая концентрация суммы липидов, в том числе большинства компонентов жирнокислотного ряда, выявлена через два месяца контакта виноматериала и вина. 
Плодоводство и виноградарство Юга России № 57(03), 2019 г.

Проведённая дегустация показала, что органолептические свойства красного столового виноматериала улучшались при продолжительности контакта до 1,5 месяцев. Дальнейшее увеличение контакта виноматериала с дрожжевой биомассой приводило к появлению выраженных дрожжевых оттенков, снижению интенсивности окраски и дегустационной оценки. В связи с этим был проведён эксперимент, целью которого было отслеживание влияния температуры и продолжительности контакта виноматериала с дрожжами на изменение концентрации фенольных соединений.

Анализируя полученные данные, можно отметить, что в процессе батонажа снижается концентрация как суммы фенольных соединений, так и антоцианов (табл. 3). При этом двукратное проведение батонажа способствовало большему снижению концентрации фенольных соединений. Для того чтобы представить наглядно изменение концентрации фенольных соединений, были проведены расчёты процентного уменьшения их концентраций в процессе батонажа.

Таблица 3 - Изменение суммы фенольных веществ и антоцианов, \% к исходному содержанию

\begin{tabular}{|c|c|c|c|c|c|c|c|c|c|c|}
\hline \multirow{6}{*}{ 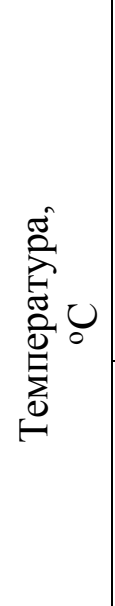 } & \multirow{5}{*}{\multicolumn{2}{|c|}{$\begin{array}{c}\text { Исходная } \\
\text { концентрация }\end{array}$}} & \multicolumn{8}{|c|}{$\begin{array}{c}\text { Продолжительность контакта виноматериалов } \\
\text { с дрожжевой биомассой }\end{array}$} \\
\hline & & & \multicolumn{4}{|c|}{1 месяц } & \multicolumn{4}{|c|}{2 месяц } \\
\hline & & & \multicolumn{4}{|c|}{ количество перемешиваний } & \multicolumn{4}{|c|}{ количество перемешиваний } \\
\hline & & & \multicolumn{2}{|c|}{1} & \multicolumn{2}{|c|}{2} & \multicolumn{2}{|c|}{1} & \multicolumn{2}{|c|}{2} \\
\hline & & & \multicolumn{4}{|c|}{ фенольные вещества } & \multicolumn{4}{|c|}{ фенольные вещества } \\
\hline & $\sum_{j}^{\frac{\pi}{\delta}}$ & 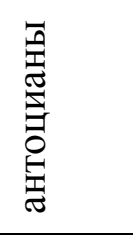 & 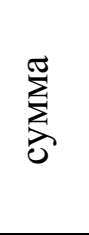 & 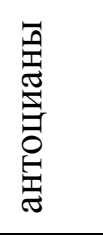 & 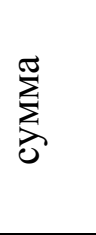 & 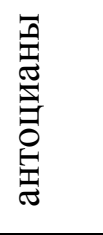 & 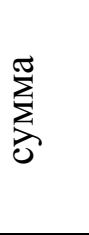 & 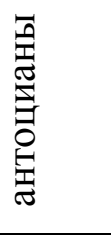 & 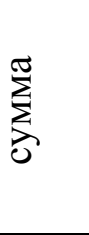 & 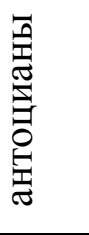 \\
\hline $3-5$ & \multirow{5}{*}{\multicolumn{2}{|c|}{$100 \%$}} & 98,4 & 88,4 & 88,1 & 83,4 & 96,1 & 78,4 & 80,1 & 78,1 \\
\hline $6-10$ & & & 97,4 & 79,4 & 96,5 & 77,2 & 95,1 & 73,2 & 93,4 & 72,0 \\
\hline $12-15$ & & & 99,3 & 79,8 & 79,1 & 75,2 & 88,9 & 74,4 & 77,8 & 71,5 \\
\hline $16-19$ & & & 98,9 & 98,3 & 97,3 & 65,9 & 96,1 & 63,4 & 96,0 & 63,4 \\
\hline$>20$ & & & 90,0 & 87,4 & 84,1 & 65,8 & 88,4 & 85,0 & 71,4 & 61,5 \\
\hline
\end{tabular}


Плодоводство и виноградарство Юга России № 57(03), 2019 г.

В результате проведённых расчётов установлено, что проведение батонажа в течение месяца при температуре $3-5^{\circ}$ или $5-10{ }^{\circ} \mathrm{C}$ и однократном перемешивании обеспечивает сохранность большей части фенольных соединений, в том числе антоцианов. При двукратном перемешивании отмечено снижение концентрации как сумы фенольных соединений, так и антоцианов. Увеличение продолжительности контакта виноматериала с дрожжами при однократном перемешивании способствовало незначительному уменьшению количества исследуемых компонентов. При втором батонаже концентрация фенольных соединений заметно снизилась.

Повышение температуры до $16-19{ }^{\circ} \mathrm{C}$ и однократном перемешивании также не привело к заметному снижению количества фенольных соединений, включая антоцианы. Второе перемешивание в течение месяца способствовало уменьшению их количества. Через 2 месяца батонажа и двукратном перемешивании отмечена наименьшая сохранность фенольных соединений.

Заключение. Статистическая обработка экспериментальных данных с помощью программ персонального компьютера (коэффициент корреляции $0,84)$ показала, что по совокупности полученных результатов в технологии красных столовых вин батонаж необходимо проводить в течение одного (возможно 1,5) месяца с однократным перемешиванием при температуре не выше $15^{\circ} \mathrm{C}$.

\section{Литература}

1.Sur lie \& bâtonnage (lees contact and stirring). [Электронный ресурс] - Режим доступа. - URL: http://www.brsquared.org/wine/Articles/surlie/surlie.htm

2.Оставление вина на дрожжевом осадке. [Электронный ресурс] - Режим доступа. - URL: http://atdrinks.ru/ostavlenie_vina_na_drojevom_osadke

3. Alexandre, H., \& Guilloux-Benatier, M. (2006). Yeast autolysis in sparkling wine - a review. Aust. J. Grape Wine Res., 12, 119-127.

4. Fornairon-Bonnefond, C., Camarasa, C., Moutounet, M., \& Salmon, J.M. (2002). New trends on yeast autolysis and wine ageing on lees: A bibliographic review. J. Int. Sci. Vigne Vin, 36, 49-69.

5. Gónzalez, R., Martínez-Rodríguez, A.J., \& Carrascosa, A.V. (2003). Yeast autolytic mutants potentially useful for sparkling wine production. Int. J. Food Microbiol., 84, $21-26$. 
6. Dussaud, A., Robillard, B., Carles, B., Duteurtre, B., \& Vignesadler, M. (1994). Exogenous lipids and ethanol influences on the foam behavior of sparkling base wines. J. Food Sci., 59, 148.

7. Авакянц С.П. Биохимические основы технологии шампанского. М., 1980. 352 с.

8. Нилов В.И., Датунашвили Е.Н, Павленко Н.М. К изучению процессов, протекающих при выдержке на дрожжах // Труды ВНИИВиВ «Магарач». Т. 9. 1970. С. 153-187.

9. Агеева Н.М., Марковский М.Г. Секреция белка при брожении и выдержке виноматериала на дрожжевом осадке // Известия вузов. Пищевая технология. 2015. № 23. C. 17-21.

10. Лисовец У.А., Агеева Н.М. Секреция ферментов из дрожжевой клетки в виноматериал в технологии белых столовых вин // Научные труды КубГТУ, 2017. № 5. C.93-106.

11. Martínez-Rodríguez, A.J., GonzÁlez, R., and Carrascosa, A.V. (2004). Morphological changes in autolytic wine yeast during aging in two model systems. J. Food Sci., 69, 233-239.

12. Полыгалина Г. В., Чередниченко В. С., Римарева Л.В. Определение активности ферментов. М.: ДеЛиПринт, 2003. - 170 с.

13. Римарева Л.В. Теоретические и практические основы биотехнологии дрожжей. -М.: ДеЛиПринт, 2003. 260 с.

14. Методы технохимического контроля в виноделии / под ред. В.Г. Гержиковой. Симферополь: Таврида, 2002. 258 с.

15. Wüthrich K. NMR Studies of Structure and Function of Biological Macromolecules (Nobel Lecture) / K. Wüthrich // Journal of Biomolecular NMR. - 2003. - Vol. 27. Is. 1. - P. 13-39.

16. Orädd, G., Westerman P. W., and Lindblom G. Lateral Diffusion Coefficients of Separate Lipid Species in a Ternary Raft-Forming Bilayer: A Pfg-NMR Multinuclear. Biophysical Journal. - 2005. - Vol. 89. - P.315- 320.

17. Chamkha, M. Phenolic composition of champagnes from Chardonnay and Pinot Noir vintages / Chamkha, M., Cathala, B., Cheynier, V. \& Douillard, R. // Journal of Agricultural and Food Chemistry. - 2003. - Vol. 51 - PP. 3179-3184

18. Cebollero, E., \& GonzÁlez, R. (2006). Induction of autophagy by secondfermentation yeasts during elaboration of sparkling wines. Appl. Environ. Microbiol., 72, 4121-4127.

19. Meer G. Membrane lipids: where they are and how they behave / G. Meer, D. R. Voelker, G. W. Feigenson // Nature Reviews Molecular Cell Biology. - 2008. - Vol. 9 -P. 112-124.

20. Feuillat, M. (2003). Yeast macromolecules: Origin, composition, and enological interest.Am. J. Enol. Vitic., 54, 211-213.

21. Klis, F.M., Mol, P., Hellingwerf, K., \& Brul, S. (2002). Dynamics of cell wall structure in Saccharomyces cerevisiae. FEMS Microbiol. Rev., 26, 239-256.

\section{References}

1. Sur lie \& bâtonnage (lees contact and stirring). [Elektronnyj resurs] - Rezhim dostupa. - URL: http://www.brsquared.org/wine/Articles/surlie/surlie.htm

2. Ostavlenie vina na drozhzhevom osadke. [Elektronnyj resurs] - Rezhim dostupa. URL: http://atdrinks.ru/ostavlenie_vina_na_drojevom_osadke

3. Alexandre, H., \& Guilloux-Benatier, M. (2006). Yeast autolysis in sparkling wine a review. Aust. J. Grape Wine Res., 12, 119-127. 
4. Fornairon-Bonnefond, C., Camarasa, C., Moutounet, M., \& Salmon, J.M. (2002). New trends on yeast autolysis and wine ageing on lees: A bibliographic review. J. Int. Sci. Vigne Vin, 36, 49-69.

5. Gónzalez, R., Martínez-Rodríguez, A.J., \& Carrascosa, A.V. (2003). Yeast autolytic mutants potentially useful for sparkling wine production. Int. J. Food Microbiol., 84, 21-26.

6. Dussaud, A., Robillard, B., Carles, B., Duteurtre, B., \& Vignesadler, M. (1994). Exogenous lipids and ethanol influences on the foam behavior of sparkling base wines. J. Food Sci., 59, 148.

7. Avakyanc S.P. Biohimicheskie osnovy tekhnologii shampanskogo. M., 1980. $352 \mathrm{s.}$

8. Nilov V.I., Datunashvili E.N, Pavlenko N.M. K izucheniyu processov, protekayushchih pri vyderzhke na drozhzhah // Trudy VNIIViV «Magarach». T. 9. 1970. S. 153-187.

9. Ageeva N.M., Markovskij M.G. Sekreciya belka pri brozhenii i vyderzhke vinomateriala na drozhzhevom osadke // Izvestiya vuzov. Pishchevaya tekhnologiya. 2015. № 23. S. 17-21.

10. Lisovec U.A., Ageeva N.M. Sekreciya fermentov iz drozhzhevoj kletki v vinomaterial $\mathrm{v}$ tekhnologii belyh stolovyh vin // Nauchnye trudy KubGTU, 2017. № 5. S.93-106.

11. Martínez-Rodríguez, A.J., GonzÁlez, R., and Carrascosa, A.V. (2004). Morphological changes in autolytic wine yeast during aging in two model systems. J. Food Sci., 69, 233-239.

12. Polygalina G. V., Cherednichenko V. S., Rimareva L.V. Opredelenie aktivnosti fermentov. M.: DeLiPrint, 2003. - 170 s.

13. Rimareva L.V. Teoreticheskie i prakticheskie osnovy biotekhnologii drozhzhej. M.: DeLiPrint, 2003. 260 s.

14. Metody tekhnohimicheskogo kontrolya v vinodelii / pod red. V.G. Gerzhikovoj. Simferopol': Tavrida, 2002. 258 s.

15. Wüthrich K. NMR Studies of Structure and Function of Biological Macromolecules (Nobel Lecture) / K. Wüthrich // Journal of Biomolecular NMR. - 2003. - Vol. 27. Is. 1. - R. 13-39.

16. Orädd, G., Westerman P. W., and Lindblom G. Lateral Diffusion Coefficients of Separate Lipid Species in a Ternary Raft-Forming Bilayer: A Pfg-NMR Multinuclear. Biophysical Journal. - 2005. - Vol. 89. - P.315- 320.

17. Chamkha, M. Phenolic composition of champagnes from Chardonnay and Pinot Noir vintages / Chamkha, M., Cathala, B., Cheynier, V. \& Douillard, R. // Journal of Agricultural and Food Chemistry. - 2003. - Vol. 51 - RR. 3179-3184

18. Cebollero, E., \& GonzÁlez, R. (2006). Induction of autophagy by secondfermentation yeasts during elaboration of sparkling wines. Appl. Environ. Microbiol., 72, 4121-4127.

19. Meer G. Membrane lipids: where they are and how they behave / G. Meer, D. R. Voelker, G. W. Feigenson // Nature Reviews Molecular Cell Biology. - 2008. - Vol. 9 - P. 112-124.

20. Feuillat, M. (2003). Yeast macromolecules: Origin, composition, and enological in-terest.Am. J. Enol. Vitic., 54, 211-213.

21. Klis, F.M., Mol, P., Hellingwerf, K., \& Brul, S. (2002). Dynamics of cell wall structure in Saccharomyces cerevisiae. FEMS Microbiol. Rev., 26, 239-256. 